\title{
A Study on Impact of Sensitive Intelligence and Perceived Stress
}

\author{
L.Vijayashree, Shishira Srinivasa
}

\begin{abstract}
This paper explores the connection between emotional understanding (EI) and Perceived stress among 40 men and 40 women students of management stream in a college. There are two hypothesis which are proved in this article. The Chadha Emotional Intelligence Test (EIT) and Perceived Stress Scale developed by Cohen, Kamarck and Mermelstein were used for the analysis. Fixed investigation has shown that EI is negatively correlated to Stress. T-test on the mean results showed no gender difference for EI and perceived position stress among students in management. The analysis underlines the significance of Emotional Intelligence for students in management.
\end{abstract}

Keywords: Sensitive Intelligence, Perceived Stress, Management students, Emotional Quotient

\section{INTRODUCTION}

$\mathrm{E}$ motional quotient (EQ) is the awareness and know-how to handle and manage harmony. This results in productivity and eternal satisfaction. Emotional Quotient is being used instead of Emotional Intelligence (EI). It can be explained in simple words as to know what sense well, how to move from the former to the latter. Last but not least, in comparison to the IQ, the EQ/EI can be strengthened for life. The EI described by Goleman (1998) indicates enhancing the capacity to understand one's own and others' feelings Self-motivation, self-control of emotions and efficient management of emotions of others. EI is described by Mayer and Salovey (1990) as "oral and non-verbal evaluations and expression of emotion, self and other emotional control, and use emotional material to solve the issue." Stress can be described as a relationship between the individual and the environment (Folkman, 1984; Lazarus 1966). Lazarus. Stress is a phase, a series of events leading to a particular process. McGrath (1970) states that stress is the product of a disparity between physical or psychological demands met and capacity to respond individuals have significant consequences for the individual in case the demands are not met. There are significant variations in how difficult circumstances are dealt with the same thing. The situation can be extremely stressful for one person, while it cannot be stressful for another at all. EI will come to our rescue in stressful situations to enable us in effectively responding to remove or minimize the

Manuscript received on March 08, 2021.

Revised Manuscript received on March 15, 2021.

Manuscript published on March 30, 2021.

* Correspondence Author

Ms Shishira Srinivasa*, Management, BNM Institute of Technology, Bangalore, India. Email: shishibenbarnes@gmail.com

Dr L.Vijayashree, Professor - MBA Dept., Head-Entrepreneurship Development Cell- BNMIT, Chief- Coordinator- New Gen IEDC, DST, GoI, BNMIT. Bangalore. Email: Professor.bnmit@gmail.com

(C) The Authors. Published by Blue Eyes Intelligence Engineering and Sciences Publication (BEIESP). This is an open access article under the CC BY-NC-ND license (http://creativecommons.org/licenses/by-nc-nd/4.0/)

perceived stress minimum effects. In relation to the EI-stress relationship, Goleman (2001) found that the emotionally competent person meets far less stress is viewed than emotionally inept stress. This study investigates the association between EI and perceived stress between students of administration. EI and perceived tension were also inspected among both genders.

\section{ASSUMPTIONS}

$\mathrm{H}-1$ : Sensitive intelligence is adversely linked to perceived stress.

$\mathrm{H}-2$ : There is a significant gender distinction in

\section{THE FOLLOWING INSTRUMENTS WERE} USED TO COLLECT THE SAMPLE DATA:

\section{Test of Emotional Intelligence:}

The lack of Emotional Intelligence explains why people who, despite having a high IQ, have been such utter failures and disastrous in their personal and professional lives. In contrast, Emotional Intelligence are poised, outgoing, committed to other people and worthy causes, sympathetic and caring, with a rich and fulfilling emotional life. It is often said that a high IQ may assure you a top position, but it may Tot make you a top person.

The emotional intelligence test was used to measure emotional intelligence (EIT), Chadha established (2001). 15 things that calculate emotional reactions situations have been taken. Crafted for Indians, the EIT was standardized for Managers, entrepreneurs, administrator and factory labours. There are 15 questions with four options. This test tests EQ by emotional response to various circumstances.

\section{Perceived Stress Scale (PSS)}

Stress has been calculated with the help of Cohen's Perceived Stress Scale (PSS), Mermelstein and Kamarck (1983). PSS has been used extensively and has its trust and validity. It was founded (Cohen and Williamson, 1988). The degree is calculated what circumstances are considered stressful in one's life. It consists of ten objects. The respondents are expected to have a score between 0 to 4 for each item (0 for-ever, 1 for ever, Almost never, 2 rarely, 3 very often and 4 quite often). Scoring has been reversed Items 4, 5, 7 and 8. The outcome indicates the following:

$\$ 0$-13 indicate low stress,

\$14-27 indicate medium stress

\$ 28-40 indicate high stress.

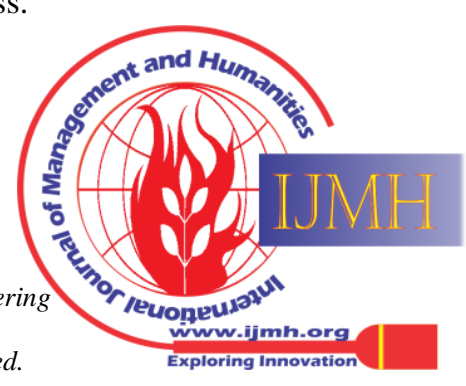




\section{A Study on Impact of Sensitive Intelligence and Perceived Stress}

\section{ANALYSIS AND RESULTS}

SPSS Software was used to determine the connection between Emotional Intelligence and perceived stress, and for this correlational analysis was performed.

Table 1: Correlation between Emotional Intelligence and Perceived Stress

\begin{tabular}{|c|l|l|}
\hline $\begin{array}{r}\text { SI. } \\
\text { NO }\end{array}$ & \multicolumn{1}{|c|}{ VARIABLES } & \multicolumn{1}{c|}{$\begin{array}{c}\text { COEFFICIENT OF } \\
\text { CORRELATION }\end{array}$} \\
\hline 1 & $\begin{array}{l}\text { Emotional Intelligence } \\
2\end{array}$ & $-0.30^{*}$ \\
\hline
\end{tabular}

The result was found to have a significant negative relationship was identified between Emotional Intelligence and perceived stress.

And further, in order to find the gender distinction in Emotional Intelligence and perceived stress, t-test was conducted.

The results are indicated in Table 2 at the end of the paper and no significant distinction had been found on EI and perceived stress between women and men groups.

\section{SUMMARY OF THE RESULTS:}

\# Evidence of the first hypothesis that higher Emotional Intelligence is correlated with less stress that's rational. With an inflated degree of EI, psychological adaptation is stronger. This showed a result in the improved trust and reduced vulnerability to unpleasant circumstances in lesser anxiety. The lesser a person has anxiety, the more his trust towards the organization. Psychological factors impact a lot with regard to stress.

\# Gohm and Clore (2002) and Gohm and Corser published similar results (as alluded to in Gohm et al., 2005).

\# Falsifying the second hypothesis reflects the students in management. The male management students on EI and perceived stress are not substantially different. In comparison, Tapia (1999) and Dunn (2002) claimed that women are different from men

\#Empathy and social responsibility are higher in their personality and women and more than males, interpersonal relationships.

\section{CONCLUSION:}

The role of Emotional Intelligence in better perceived stress management has been shown in this research. It is also evident that those who are high in EI prefer to rise engaged in their work. This dedication is perceived as a result of targets, good working relationships with their colleagues, frequent participation, and constructive engagement in day-to-day events. Analysis of the Jaeger (2003). EI has been stated to have a strong association with academic success. EI plays an important role in managing stress.

\section{REFERENCES}

1. Chadha N K (2001), "Indian Prime Ministers and their EQ", Master of Human Resources and Organizational Development (MHROD) Bulletin, Delhi School of Economics, University of Delhi, Delhi.

2. Cohen S, Kamarck T and Mermelstein R (1983), "Global Measure of Perceived Stress", Journal of Health and Social Behavior, Vol. 24, pp. 385-96.

3. Cohen W M and Levinthal D A (1990), "Absorptive Capacity: A New Perspective on Learning and Innovation", Administrative Science Quarterly, Vol. 35, No. 1, pp. 128-152

4. Fisher A B (1992), "Working Women: When will Women Get to the Top", Fortune, Vol. 21, September, pp. 44-56.

5. Gallivan M J (2002), "The Influence of Software Developers' Creative Style on Their Attitudes to and Assimilation of a Software Process Innovation", Journal of Engineering Technology and Management, Vol .19, pp. 141-165.

6. Greenhaus J H, Callanan G A (1994), Career Management, 2nd Edition, The Dryden Press, Fort Worth, TX.

7. Hofstede G (1991), Organizations and Cultures: Software of the Mind, McGraw-Hill, London.

8. Igbaria M and Chidambaram L (1997), "The Impact of Gender on Career Success of Information Systems Professionals: A Human-Capital Perspective", Information Technology and People, Vol. 10, No. 1, pp. 63-76.

9. Igbaria M and Greenhaus J H (1992), "Determinants of MIS Employees Turnover Intentions: A Structural Equation Model”, Communications of the ACM, Vol. 35, No. 2, pp. 34-49.

10. Ilgen D R and Youtz M A (1986), "Factors Affecting the Evaluation and Development of Minorities in Organizations", in Rowland K and Ferris G (Eds.), Research in Personnel and Human Resource Management: A Research Annual, pp. 307-337

11. Johnson M (1990a), "Women Under the Glass", Computerworld, December 3, pp. 93-95.

12. Johnson M (1990b), "Career Boosters for Women”, Computerworld December 10, p. 95

Table- II: Indicating the $\mathbf{t}$ test done And further, in order to find the gender distinction in Emotional Intelligence and perceived stress, t-test was conducted.

The results are indicated in Table 2. No significant distinction had been found on EI and perceived stress between women and men groups

Table 2: Gender Distinction on Emotional Intelligence and Perceived Stress

\begin{tabular}{|c|c|c|c|c|c|c|c|}
\hline \multirow[t]{2}{*}{ Groups } & \multicolumn{3}{|c|}{ Emotional Intelligence } & \multicolumn{4}{|c|}{ Perceived Stress } \\
\hline & Mean & SD & T-Value & & & SD & T-Value \\
\hline Female $\mathrm{N}=40$ & 237.19 & 27.02 & $0.44 \#$ & 19.02 & 4.44 & & \\
\hline Male $\mathrm{N}=40$ & 233.17 & 34.01 & & 18.18 & 3.19 & & \\
\hline
\end{tabular}

Note: Degree of freedom = 60; \# Not Significant

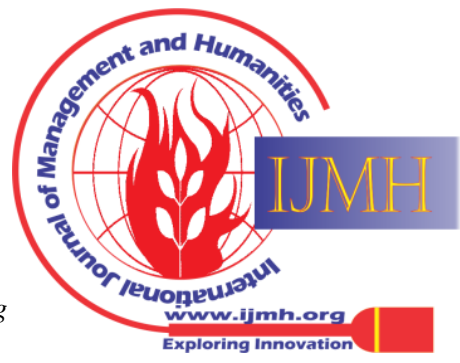




\section{AUTHORS PROFILE}

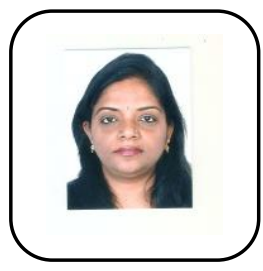

Dr. L. Vijayashree, Experience:

- Head-Entrepreneurship Development CellBNMIT and Chief- Coordinator- New Gen IEDC, DST, GoI, from 2017.

- Head and Professor of MBA - 3 Years, Academic experience in total -17 years, Industry experience - 4 years.

Journals \& book's Publication: 56 International Journal Paper and National Research papers (citation factor- 75). Also presented Research papers and won outstanding paper awards in International conferences held abroad and in India.

Published Books for undergraduate students in the areas of Business Environment, Organizational Behavior and Strategic Management.

Grants: Chief coordinator-Entrepreneurship Development Cell at BNMIT received many grants as Principal Investigator for the following Department of Science and Technology (DST) projects:

1. DST - NewGen IEDC (Innovation Entrepreneurship Development Cell) 2017- 2022

INR 2, 87, 50,000/- for students project prototype development.

2. DST - NIMAT(National Implementing and Monitoring Agency for Training) Project 2018 - 2019 -

INR. 2, 00, 000/- for 10 Entrepreneurship Awareness Camp.

3. DST - NIMAT(National Implementing and Monitoring Agency for Training) Project 2017 - 2018 -

INR. 1, 00, 000/- for 5 Entrepreneurship Awareness Camp.

4. DST - NIMAT(National Implementing and Monitoring Agency for Training) Project 2015 - 2016 -

IINR 40, 000/- for 2 Entrepreneurship Awareness Camp.

PhD Guidance: Three of the $\mathrm{PhD}$ research scholars are awarded Doctorate under VTU and two are in the verge of submitting their final thesis in the areas of Stress, E-Governance and change management, Leadership, Role Efficacy and Locus of control areas.

Journal Editorial Boards: AMC Indian Journal of Entrepreneurship, Member of scientific Technical committee and editorial Board on Arts , Management and social sciences assisted by King Mongkut's University of Technology Thonburi, Thailand, Advisory editor of Mustang Journal of Law and Legal Studies, USA, Editorial Board Member for International Journal of Social Science Research, USA, Indian Journal of Entrepreneurship, Reviewers committee in International Journal of Human Resource management, FOREX -Technical Journal, CMS Journal of Management -India.

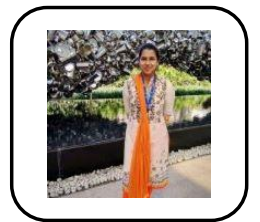

Ms Shishira Srinivasa

1. Currently working as a Senior Tax Consultant at KPMG, Bangalore, and a Part time PhD Research Scholar at BNMIT, Bangalore.

2. Industry Experience: 5.5 years

3. Journals and Publications: 11 National and International Journal publications and a chapter contribution in Perspectives of Business Management Volume 1.

4. Presented papers at National conference and got them published in their Journals.

5. Is about to submit her thesis in less than 3 months' time in the area of stress management.

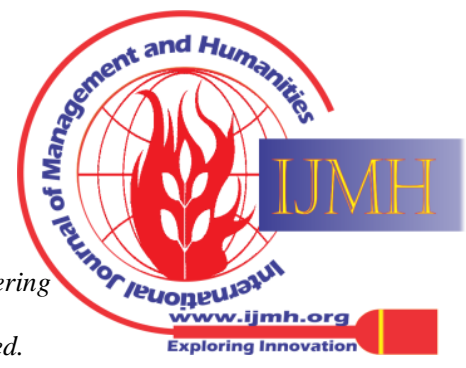

